\title{
A MODIFIED PERTURB AND OBSERVE TECHNIQUE FOR MPPT OF INTGRATED PV SYSTEM USING DC-DC BOOST CONVERTER
}

\author{
Ibram Y. Fawzy*1, Yehia S. Mohammed ${ }^{1}$, E. G. Shehata ${ }^{1}$, Montaser Abd El Sattar ${ }^{2}$ \\ ${ }^{I}$ Electrical Engineering Department, Faculty of Engineering, Minia University, Minia, Egypt \\ ${ }^{2}$ Department of Electrical and Computers Engineering, El-Minia High Institute of Engineering and Technology, \\ Minia, Egypt \\ . corresponding author E-mail: ibramyehia@yahoo.com
}

\begin{abstract}
A photovoltaic system (PV) connected to the utility grid through three-phase voltage source inverter (VSI) has been controlled in this paper for achieving maximum power point tracking (MPPT). In this paper, a modified perturb and observe $(\mathrm{P} \& \mathrm{O})$ technique has been proposed for achieving MPPT of PV system using DC-DC boost converter. The proposed algorithm is used to obtain better capture of energy with minimum steady state oscillations. In this technique, the duty cycle is determined using a variable step-size to achieve MPPT accurately. A digital simulation using Matlab/Simulink package is carried out to demonstrate the advantage of the proposed system performance compared to the conventional technique under varying irradiation and temperature levels. The obtained results investigate that the modified algorithm can track the maximum power point (MPP) accurately besides, it extracts the additional power during the variation in weather conditions as compared to the conventional $\mathrm{P} \& \mathrm{O}$ algorithm.
\end{abstract}

Keywords: PV System, Boost Converter, MPPT, Modified P\&O, VSI and Utility Grid.

\section{INTRODUCTION}

Due to the decrease of conventional energy sources and the rising problem of environmental pollution, the research and utilization about the renewable energy sources, such as solar energy, wind energy as so on, have been in favor of more and more attention [1].

The Photovoltaic (PV) system has some benefits such as environment friendly "pollution free" and low maintenance cost. The main drawbacks of PV are it needs a high installation cost and it has a low efficiency as its efficiency is not more than $20 \%$ [2].
PV grid-connected systems are the most commonly and widely used nowadays. They do not need storage batteries and they use common inverters and are connected to the utility grid. Any excess energy produced from PV system is exported to the electricity grid and we usually get paid credit for the energy exported by the system. The PV ongrid systems are shut down during a power failure due to safety reasons [3].

The efficiency of PV system depends on many factors such as sun irradiation, temperature, dirt, shadow and spectral characteristics of sunlight. The climatic changes can reduce the output power of PV array. A lot of research has been done to improve the efficiency of the PV modules. A number of methods to track the maximum power point (MPP) of a PV module have 
been proposed to overcome the limitation of efficiency $[1,4]$.

Maximum power point tracking (MPPT) is used to obtain maximum power from the photovoltaic module by properly adjusting the duty cycle of the DC-DC converter. Various MPPT algorithms have been employed by the researchers in several papers. Perturb and observe ( $\mathrm{P} \& \mathrm{O})$ technique: it observes the voltage level and perturbs the voltage till it holds MPP. Incremental conductance (INC) technique: it compares the slope of the power curve and determines whether to increase or decrease the duty ratio in order to achieve MPPT [5]. $\mathrm{P} \& \mathrm{O}$ can be used for the system which is required simplicity of system and for highly complicated system we can use INC because of its complexity and high cost [6].

The conventional $\mathrm{P} \& \mathrm{O}$ has some disadvantages such as slow response speed, oscillation of the operating point around the MPP in steady state, and even tracking in the wrong way under rapidly changing in the atmospheric conditions [7]. The modified algorithm can overcome these problems with using a variable step-size instead of a fixed one [8].

Muralidhar, K. and Susovon, S (2015) [18] described a modified P\&O MPPT for PV array using variable step-size. The variable step size is a function of the power to voltage derivative of PV system. This system suffers from some oscillations.

This paper presents control of PV grid connected system based on a modified P\&O algorithm for achieving MPPT. The performance integrated PV systems for the both conventional and modified algorithm are compared using Matlab/Simulink software backage.The obtained results investigated that MPPT can be achieved precisely with the modified technique with less oscillation as compared to the conventional one.

\section{DESCRIPTION OF SYSTEM UNDER STUDY}

Figure 1 shows a typical PV array via DC-DC boost converter connected to grid through three-phase voltage source inverter (VSI) and passive filter. The system contains the following components:

1. PV array to deliver a maximum of 100 $\mathrm{kW}$ at different irradiance and temperature levels.

2. DC-DC boost converter to increase the voltage output of PV from 273.5 V DC to $500 \mathrm{~V}$ DC.

3. Three-level three-phase VSI to convert the DC voltage delivered by the array of $\left(\begin{array}{lll}500 & \mathrm{~V}\end{array}\right)$ to an AC voltage of $220 \mathrm{~V}$ and also to keep a unity power factor.

4. Passive filter

5. Utility grid.

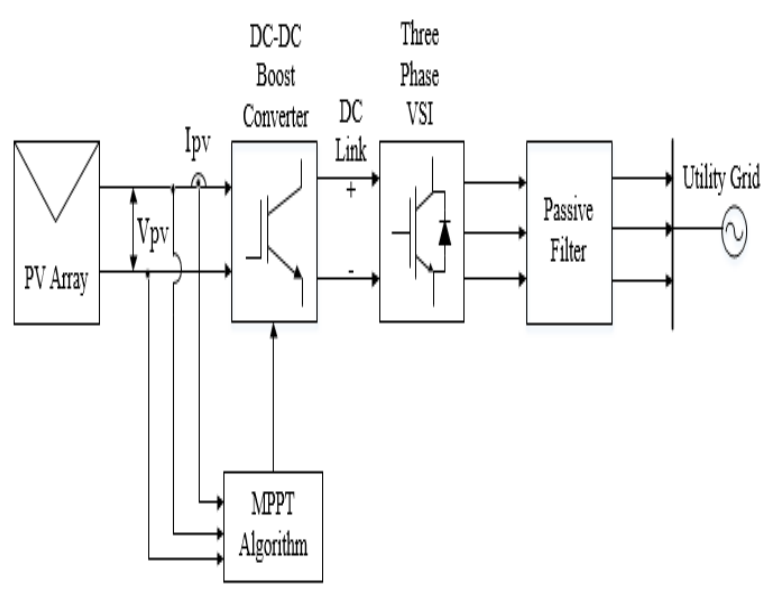

Fig.1: PV array grid-connected system.

\subsection{PV model}

The simplified PV model can be represented as single diode model as shown in figure 2. 


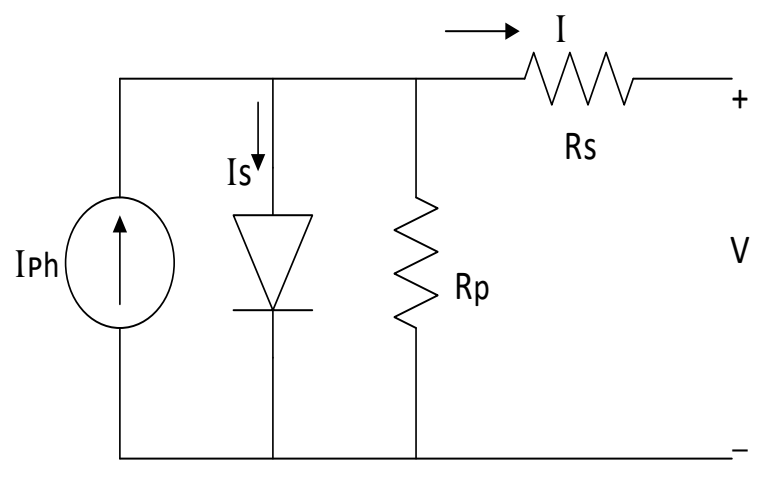

Fig.2: Single diode model.

The basic equation that describes the I-V characteristics of the PV model is given by the following equation:

$I=I_{p h}-I_{S}\left[e^{\frac{q(V+I R s)}{K T}}-1\right]-\frac{V+I_{S}}{R_{P}}$

The light generated current, $\mathrm{I}_{\mathrm{ph}}$ is a function of temperature and solar insolation is given as follows:

$\mathrm{I}_{\mathrm{ph}}=\left(\frac{\mathrm{G}}{\mathrm{G}_{\mathrm{STC}}}\right)\left[\mathrm{I}_{\mathrm{ph} \text { at STC }}+\mathrm{K}_{\mathrm{i}}\left(\mathrm{T}-\mathrm{T}_{\mathrm{STC}}\right)\right]$

The single diode saturation current as function of working PV temperature is given as follows:

$\mathrm{I}_{\mathrm{S}}=\mathrm{I}_{\mathrm{S} \text { at } \mathrm{STC}}\left(\frac{\mathrm{T}}{\mathrm{T}_{\mathrm{STC}}}\right)^{3} \exp \left[\left(\frac{\mathrm{q} \cdot \mathrm{E}_{\mathrm{g}}}{\mathrm{a} \cdot \mathrm{k}}\right)\left(\frac{1}{\mathrm{~T}_{\mathrm{STC}}}-\frac{1}{\mathrm{~T}}\right)\right]$ (3) [9].

The most widely used PV technologies are the polycrystalline (p-Si), mono- crystalline (m-Si) and amorphous silicon (a$\mathrm{Si})$ ones. The efficiency of the most commonly used $\mathrm{m}-\mathrm{Si}$ and $\mathrm{p}-\mathrm{Si}$ modules is typically between $10-18 \%$ in the EU.The aSi PV technology is a type of thin film PV technology, which nowadays has a maximum of efficiency $10.5 \%$. PV cells are connected in series and parallel to form PV module. The PV modules can be connected in series and parallel to form PV array or system [10].

The PV system represented in this paper consists of photovoltaic array. The 100-kW PV array consists of 66 modules connected in series and 5 modules connected in parallel $(66 \times 5 \times 305.2 \mathrm{~W}=100.7 \mathrm{~kW})$. Manufacturer specifications for the module «SunPower SPR-305 » are listed in table 1. The PV array block has two inputs that allow varying weather conditions (input 1 in $\mathrm{W} / \mathrm{m}^{2}$, input 2 in degree $\mathrm{C}$ ). The solar irradiance and temperature profiles are shown in figure 10. The characteristics I-V and $\mathrm{P}-\mathrm{V}$ array is shown in figure 3.

Table 1: Specifications of PV module.

\begin{tabular}{|l|l|}
\hline PV model & SunPower SPR-305-WHT \\
\hline No.of cells & 96 in series \\
\hline Maximum power & $305 \mathrm{~W} /$ One Module \\
\hline Short circuit current(Isc) & $5.96 \mathrm{~A}$ \\
\hline Open circuit voltage(Voc) & $64.2 \mathrm{~V}$ \\
\hline Max.power current(Imp) & $5.58 \mathrm{~A}$ \\
\hline Max.power voltage(Vmp) & $54.7 \mathrm{~V}$ \\
\hline
\end{tabular}



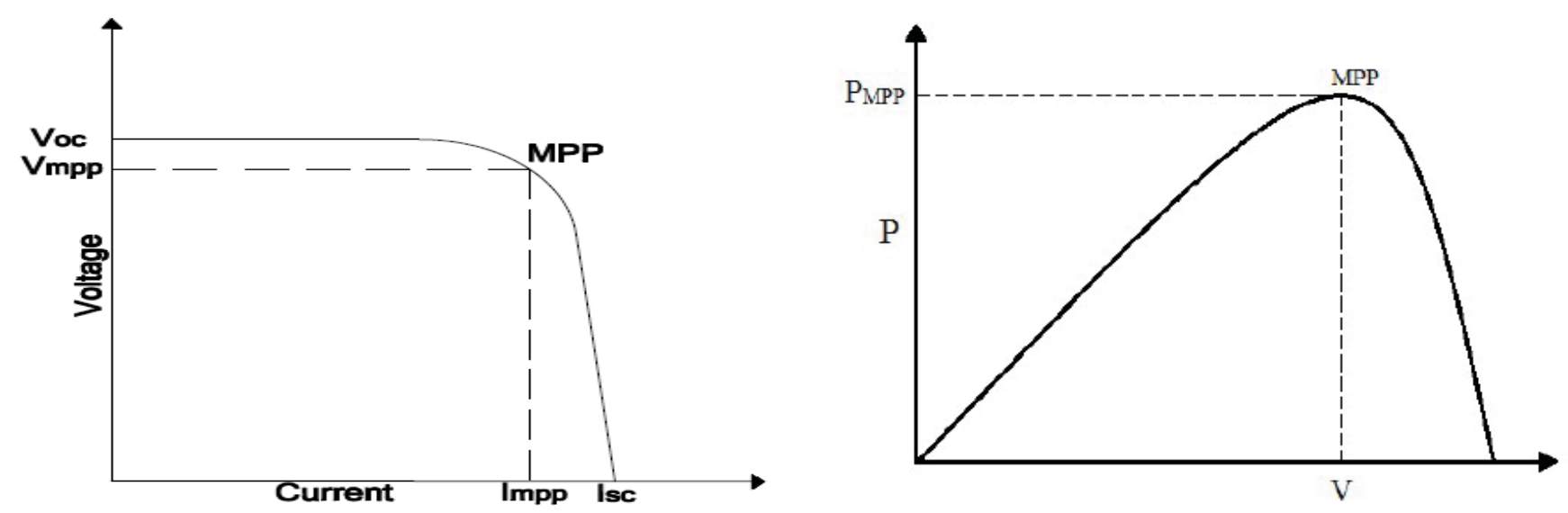

Fig.3: The characteristics I-V and P-V of PV array [11].

\subsection{Boost converter model}

DC-DC converter is used to convert unregulated DC input voltage into regulated DC output voltage at a specified voltage level. Basic converter that steps up or steps down voltage input contains elements like transistors, diodes, inductors and capacitors. There are three basic converter topologies which are buck (step-down), boost (step-up) and buck boost (step-up or step-down). In our proposed system boost converter topology is used in order to increase the PV array voltage to a level that ensures correct operation of the inverter. Stepping up the input voltage is achieved by storing energy in an inductor for a certain time period, and then uses this energy to boost the input voltage to a higher level. The optimum load impedance of PV module is achieved by varying duty cycle. The circuit diagram for a boost converter is shown in figure 4 . When switch $\mathrm{S}$ is closed, the input source charges up the inductor while diode is reverse biased to provide isolation between the input and the output of the converter. When the switch is opened, energy stored in the inductor and the power supply is transferred to the load.

The modeling equations obtained by the Kirchhoff's laws, are as follows [12, 13]:

$$
\begin{aligned}
& \frac{\mathrm{dI}_{\mathrm{L}}}{\mathrm{dt}}=\frac{1}{\mathrm{~L}}\left[\mathrm{~V}_{\text {in }}-(1-\mathrm{d}) \mathrm{V}_{\text {out }}\right] \\
& \frac{\mathrm{dV}_{\text {out }}}{\mathrm{dt}}=\frac{1}{\mathrm{C}_{\mathrm{DC}}}\left[(1-\mathrm{d}) \mathrm{I}_{\mathrm{L}}-\mathrm{I}_{\text {inv }}\right]
\end{aligned}
$$

The relationship between the input and output voltages is given by:

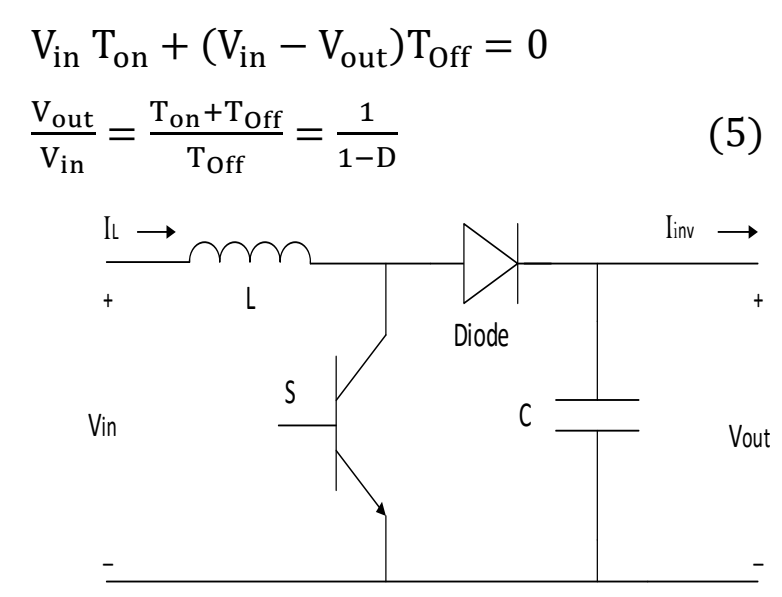

Fig.4: Schematic diagram of a DC boost converter.

\subsection{Inverter}

PV modules generate direct current and voltage (DC). It is required alternating current and voltage (AC) to connect the PV modules to the grid. Inverter is the equipment used to convert DC to AC . There are different inverter configurations, one of these is Voltage Source Inverter (VSI). It is used to convert the $500 \mathrm{~V}$ DC link voltages to $220 \mathrm{~V}$ $\mathrm{AC}$ and keeps power factor at unity [4]. 


\section{A Modified P\&O Technique}

The conventional P\&O method can track the MPP using fixed step-size which determines the duty cycle necessary for switching the DC-DC converter. The fixed step size tracking have certain drawbacks like slow speed and large steady state oscillations. If the step-size is high, it will result in faster dynamics but steady state oscillations. In contrast if small steps are chosen the tracking process will slow down. So to overcome these problems of fixed stepsize, a modified $\mathrm{P} \& \mathrm{O}$ technique is used which uses a variable step-size to improve the dynamic performance and reduce steady state oscillations [8].

The modified $\mathrm{P} \& \mathrm{O}$ technique is based on the perturbation in PV array output voltage and then the resulting variation of power is observed [14] in order to achieve MPPT. If the perturbation leads to increase in the PV output power, the actual operating point is positioned in the left side of MPP and the voltage is increased, otherwise the operating point is located in the right side and the

voltage is decreased. This process is continued until MPP is reached [15]. The modified $\mathrm{P} \& \mathrm{O}$ algorithm can be explained based on the conventional one represents by $\mathrm{P}-\mathrm{V}$ curve [16] as shown in figure 6. The related equations that describe this algorithm are described as follows [15]:

$$
\begin{cases}\frac{d P_{P V}}{d V_{P V}}=0 & \text { at MPP } \\ \frac{d P_{P V}}{d V_{P V}}>0 & \text { at left side of MPP } \\ \frac{d P_{P V}}{d V_{P V}}<0 & \text { at right side of MPP }\end{cases}
$$

It is impossible to achieve precise MPP $\left(\frac{\mathrm{dP}_{\mathrm{PV}}}{\mathrm{dV}_{\mathrm{PV}}}=0\right)$. Therefore, more investigating format is: $\left(\frac{d P_{P V}}{d V_{P V}}<\varepsilon\right)$ which a small error is allowable. The size of this permissible error (ع) determines the sensitivity of the system [17].

A variable step-size is chosen in [18-20] to improve the performance of PV system as mentioned by equations (8) and (9), where SF is the scaling factor for adjusting step size and adopting the performance of MPPT. The variable step-size is a function of the power to voltage derivative of PV system. It is given as follows:

$\mathrm{VSS}=\left|\frac{\mathrm{dP}_{\mathrm{PV}}}{\mathrm{dV}_{\mathrm{PV}}}\right| \times \mathrm{SF}$

The duty cycle of the converter at instant $\mathrm{k}$, $\mathrm{D}(\mathrm{k})$ is given by the following equation:

$\mathrm{D}(\mathrm{k})=\mathrm{D}(\mathrm{k}-1) \pm \mathrm{VSS}$

The equation (10) can be written as:

$$
\mathrm{D}(\mathrm{k})=\mathrm{D}(\mathrm{k}-1) \pm\left|\frac{\mathrm{dP} \mathrm{PV}_{\mathrm{PV}}}{\mathrm{d} V_{\mathrm{PV}}}\right| \times \mathrm{SF}
$$

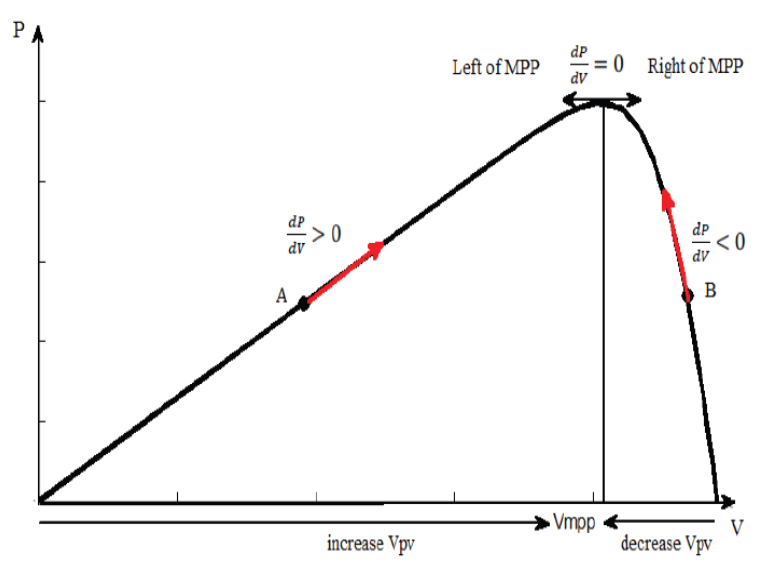

Fig. 5: The modified P\&O MPPT on P-V curve.

However, the use of PV power to voltage derivative $\left(\frac{d P_{P V}}{d V_{P V}}\right)$ in equation (9) would have several problems which can be 


\section{Vol. 40, No. 1. January 2021}

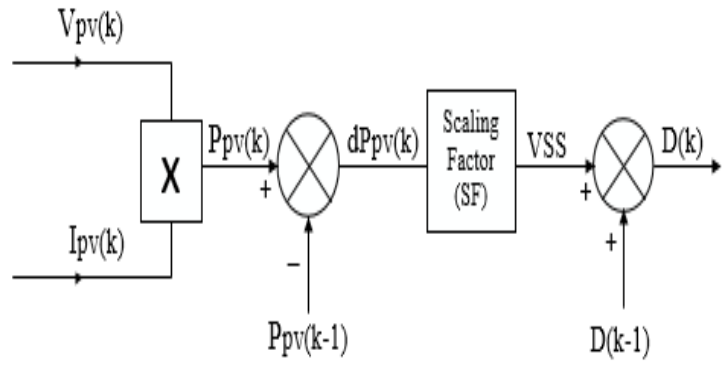

Fig.6: Block diagram of the modified $\mathrm{P} \& \mathrm{O}$ algorithm. mentioned below as follows:

1 - If the PV voltage change $\left(\mathrm{dV}_{\mathrm{PV}}\right)$ is low, the derivative $\left(\frac{d P_{P V}}{d V_{P V}}\right)$ will be large. As a result the power oscillations are increased.

2- If the $\mathrm{PV}$ voltage change $\left(\mathrm{dV}_{\mathrm{PV}}\right)$ is large, the derivative $\left(\frac{\mathrm{dP}_{\mathrm{PV}}}{\mathrm{dV_{ \textrm {PV } }}}\right)$ will be low. As a result the power oscillations are decreased but the time response of the tracking process would take more time to reach MPP.

Therefore, the proposed MPPT technique can overcome these problems. In this method a variable step-size (VSS) is used which depends only on the PV power change $\left(\mathrm{dP}_{\mathrm{PV}}\right)$ instead of the derivative $\left(\frac{d P_{P V}}{d V_{P V}}\right)$.In this case the VSS can be calculated as:

$\mathrm{VSS}=\left|\mathrm{dP}_{\mathrm{PV}}\right| \mathrm{x} \mathrm{SF}$

The duty cycle of the converter at instant $\mathrm{k}$, $\mathrm{D}(\mathrm{k})$ is obtained by the following equation:

$$
\mathrm{D}(\mathrm{k})=\mathrm{D}(\mathrm{k}-1) \pm\left|\mathrm{dP}_{\mathrm{PV}}\right| \mathrm{x} \mathrm{SF}
$$

The procedures of the modified $\mathrm{P} \& \mathrm{O}$ technique to evaluate the duty cycle for switching the converter is described by the flowchart given in figure 8.In this method, The PV output voltage and current are measured at instant $\mathrm{k}$ and compared to the previous values at instant k-1 to calculate $d V_{P V}, d V_{P V}$ and $\frac{d P_{P V}}{d V_{P V}}$. The essential steps to estimate the duty cycle of the converter can be explained by the following block diagram shown in figure 6 . 
Vol. 40, No. 1. January 2021

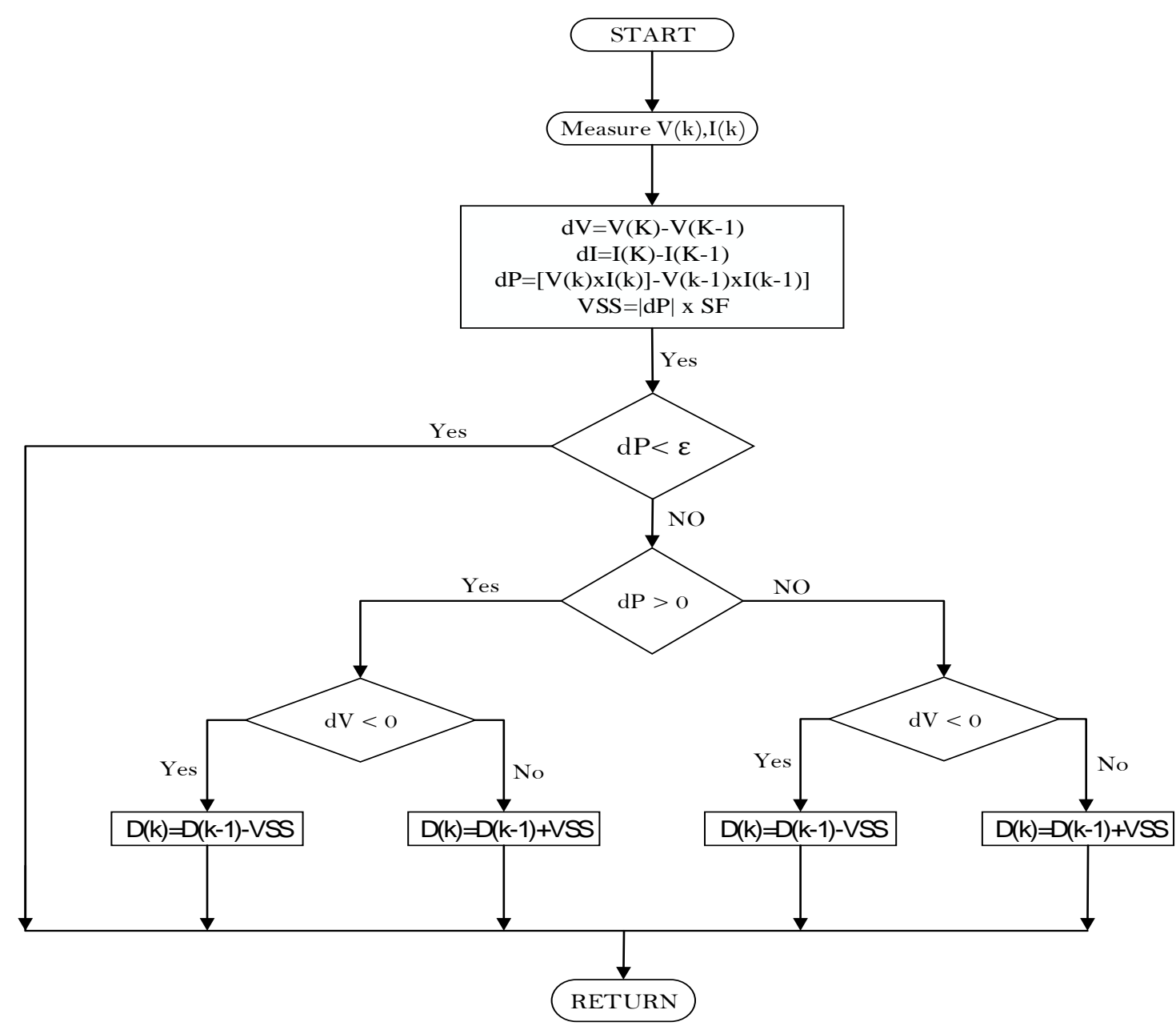

Fig.7: Flowchart of the modified $\mathrm{P} \& \mathrm{O}$ technique.

\section{SIMULATION RESULTS AND}

\section{DISCUSSION}

Digital simulation is carried out based on the proposed system shown in figure 8 using Matlab/Simulink software package. In the present study, the system is started with standard test condition "STC" $\left(25^{\circ} \mathrm{C}\right.$ and
$1000 \mathrm{~W} / \mathrm{m}^{2}$ ) and during time period the irradiance $(\mathrm{G})$ and the temperature (T) are changed as shown in figure 9 in order to explain the effect of climate condition change on the performance of PV system. 


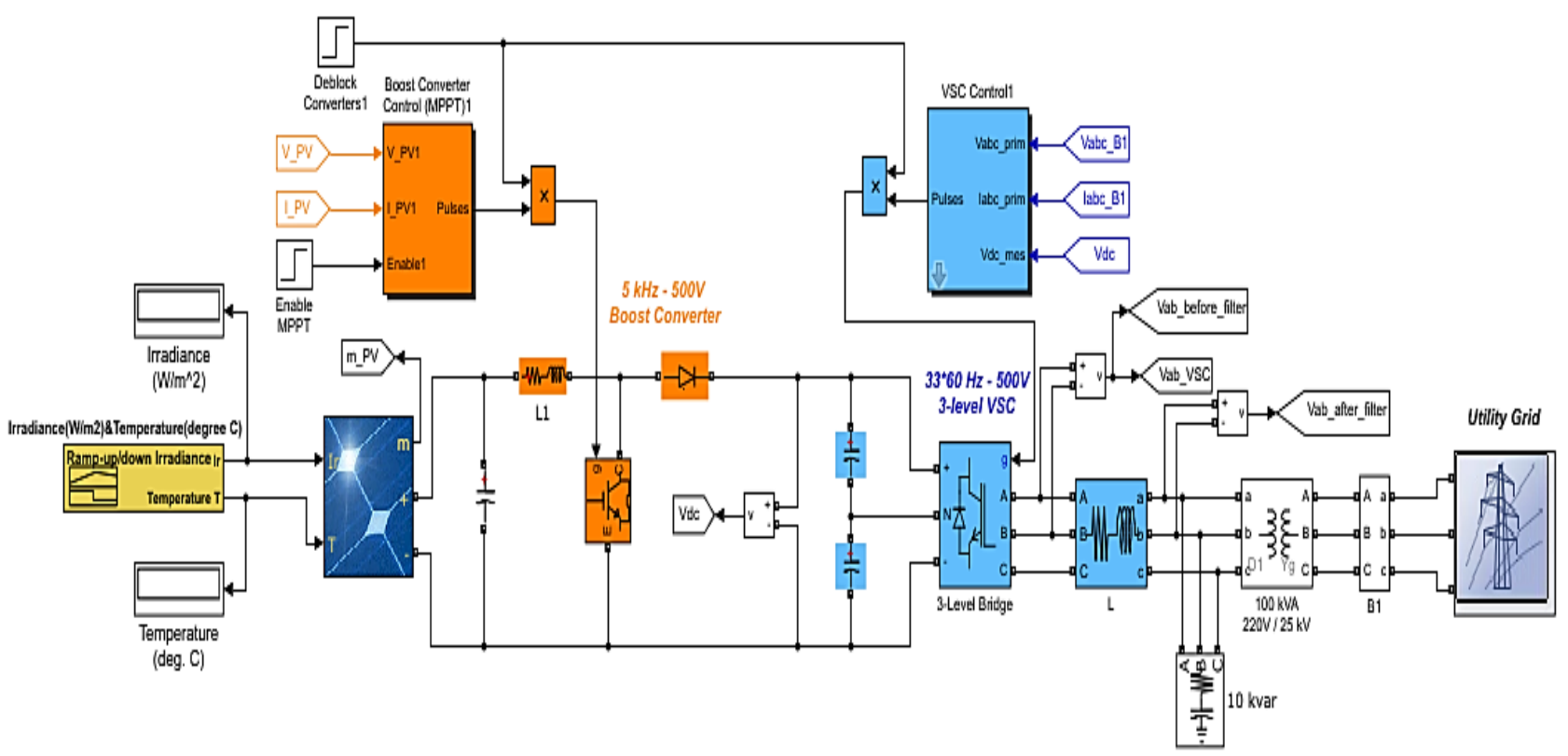

Fig.8: Whole PV grid-connected system in Matlab/Simulink.

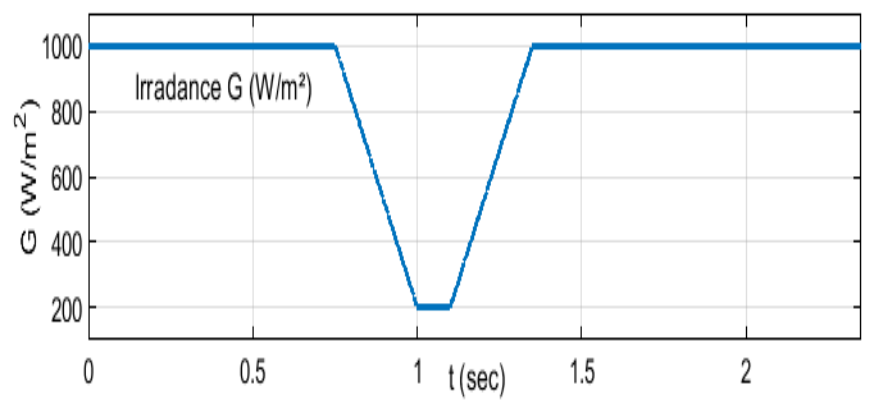

(a) : Irradiance $(\mathrm{G})$ change.

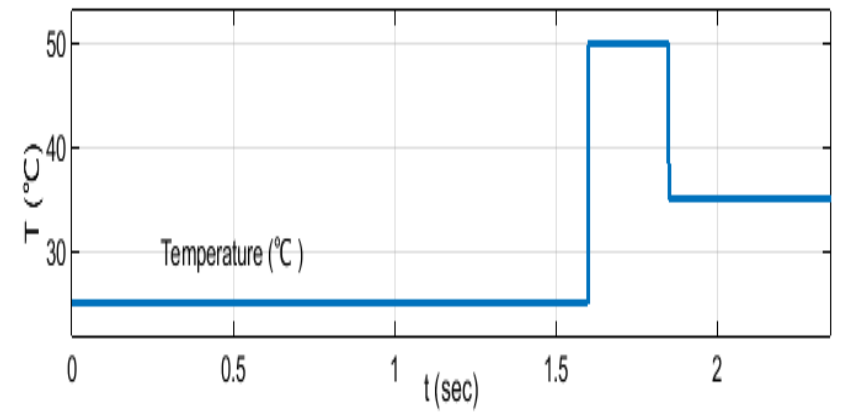

(b) : Temperature(T) change.

Fig.9: Climate condition change.

Figure 10 shows the performance of PV array connected to grid during variation of irradiance $(\mathrm{G})$ and temperature $(\mathrm{T})$ without MPPT. The output voltage of PV $\left(\mathrm{V}_{\mathrm{PV}}\right)$ is slightly decreased and increased according to the variation of $\mathrm{G}$ in the period $(\mathrm{t}=0.75 \mathrm{sec}$ to $\mathrm{t}=1.35 \mathrm{sec}$ ), while, this output voltage is reduced slightly according to the variation of $\mathrm{T}$ in the period $(\mathrm{t}=1.6 \mathrm{sec}$ to $\mathrm{t}=1.85 \mathrm{sec})$ as shown in figure 11.a. Figure 11.b shows the time response of the output current of $\mathrm{PV}$ $\left(\mathrm{I}_{\mathrm{PV}}\right)$ during variation of irradiance $(\mathrm{G})$ and temperature (T). From this figure, the output current is decreased and increased according to the variation of irradiance in linear fashion the period $(t=0.75 \mathrm{sec}$ to $\mathrm{t}=1.35 \mathrm{sec})$. On the other hand, this output current is decreased slightly due to the temperature variation in the period $(\mathrm{t}=1.6 \mathrm{sec}$ to $\mathrm{t}=1.85 \mathrm{sec})$. Also, the time response of output power of PV array $\left(\mathrm{P}_{\mathrm{PV}}\right)$ is shown in figure 11.c. This figure indicates that the variation of $\mathrm{P}_{\mathrm{PV}}$ is depended on the variation of $V_{P V}$ and $I_{P V}$. The value of the output power generated from the PV array is approximately equal to $94.3 \%$ from its maximum value $(95.37 \mathrm{~kW})$. The duty cycle of DC-DC boost converter is almost constant as shown in figure 11.d because the PV system does not operate at MPPT. 

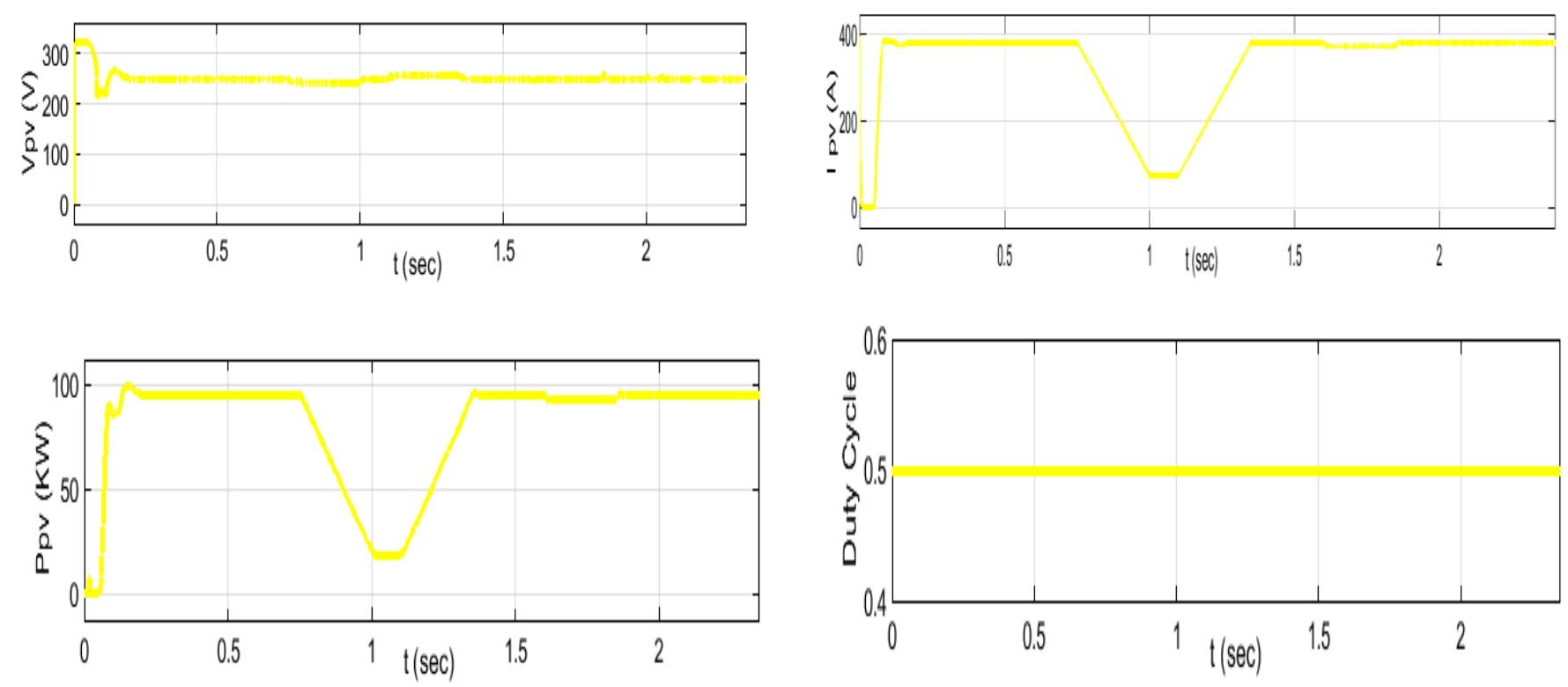

(a): The PV array output voltage $\left(\mathrm{V}_{\mathrm{PV}}\right)$.

(b): The PV array output current $\left(\mathrm{I}_{\mathrm{PV}}\right)$.

(c): The PV array output power $\left(\mathrm{P}_{\mathrm{PV}}\right)$.

(d): The duty cycle of the converter.

Fig.10: The performance of PV array during variation of irradiance $(G)$ and temperature $(T)$ without MPPT.

Figure 11 shows the performance of PV array connected to grid during variation of irradiance $(\mathrm{G})$ and temperature $(\mathrm{T})$ with the conventional $\mathrm{P} \& \mathrm{O}$ algorithm. The output voltage of $\mathrm{PV}\left(\mathrm{V}_{\mathrm{PV}}\right)$ is slightly decreased and increased according to the variation of $\mathrm{G}$ in the period ( $\mathrm{t}=0.75 \mathrm{sec}$ to $\mathrm{t}=1.35 \mathrm{sec}$ ), while, this output voltage is reduced according to the variation of $\mathrm{T}$ in the period $(\mathrm{t}=1.6 \mathrm{sec}$ to $\mathrm{t}=1.85 \mathrm{sec}$ ) as shown in figure 12.a. Figure 12.b shows the time response of the output current of $\mathrm{PV}\left(\mathrm{I}_{\mathrm{PV}}\right)$ during variation of irradiance $(\mathrm{G})$ and temperature $(\mathrm{T})$. From this figure, the output current is decreased and increased according to the variation of irradiance in linear fashion the period $(\mathrm{t}=0.75$ sec to $\mathrm{t}=1.35 \mathrm{sec})$. On the other hand, this output current is decreased slightly due to the temperature variation in the period $(\mathrm{t}=1.6 \mathrm{sec}$ to $\mathrm{t}=1.85 \mathrm{sec})$. Also, the time response of output power of $\mathrm{PV}$ array $\left(\mathrm{P}_{\mathrm{PV}}\right)$ is shown in figure 12.c. This figure illustrates that the variation of $\mathrm{P}_{\mathrm{PV}}$ is depended on the variation of $V_{P V}$ and $I_{P V}$. The value of the output power generated from the PV array is approximately equal to $97.5 \%$ from its maximum value $(98.25 \mathrm{~kW})$. The duty cycle of DC-DC boost converter is adjusted to improve the power generated from the PV array as shown in figure 12.d. In this method, the output power of PV array is improved with using the conventional MPPT. However, the output power response suffers from some oscillations. 


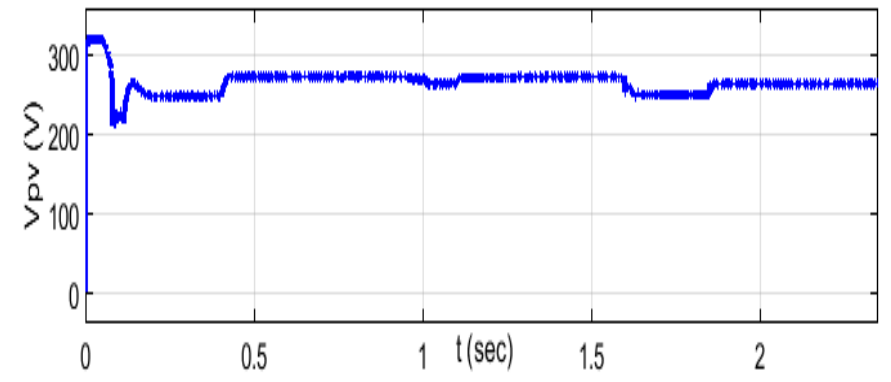

(a): The PV array output voltage $\left(\mathrm{V}_{\mathrm{PV}}\right)$.

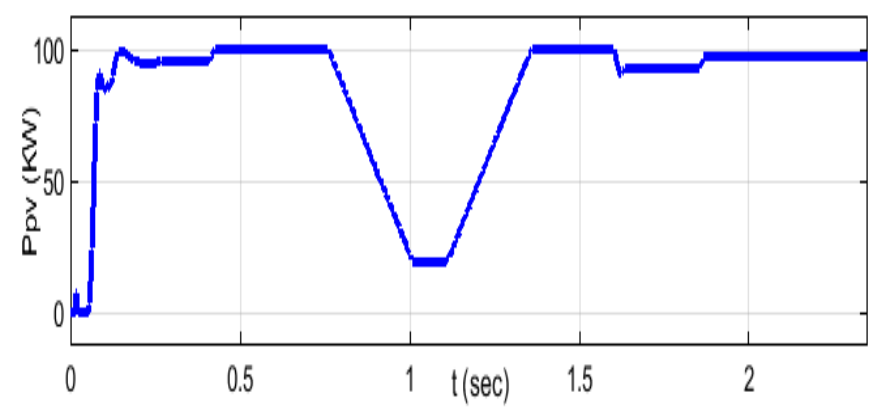

(c): The PV array output power $\left(\mathrm{P}_{\mathrm{PV}}\right)$.

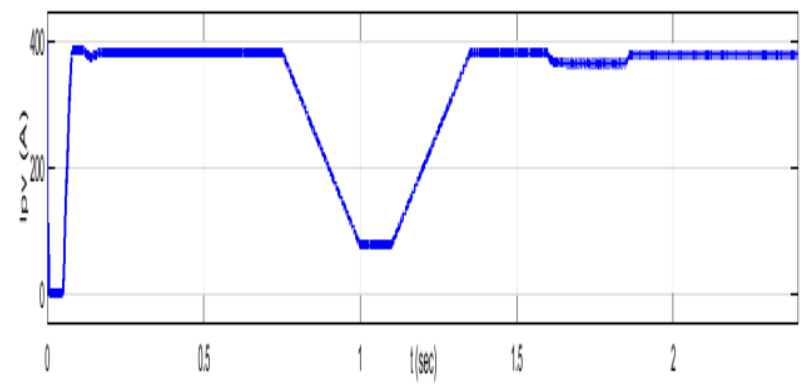

(b): The PV array output current $\left(\mathrm{I}_{\mathrm{PV}}\right)$.

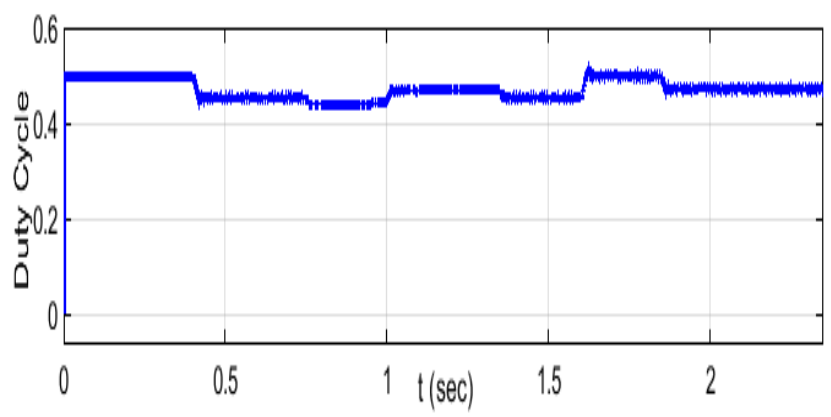

(d): The duty cycle of the converter.

Fig.11: The performance of PV array during variation of irradiance $(\mathrm{G})$ and temperature $(\mathrm{T})$ with the conventional P\&O algorithm.

Figure 12 shows the performance of PV array connected to grid during variation of irradiance $(\mathrm{G})$ and temperature $(\mathrm{T})$ with the modified $\mathrm{P} \& \mathrm{O}$ algorithm. The output voltage of $\mathrm{PV}\left(\mathrm{V}_{\mathrm{PV}}\right)$ is slightly decreased and increased according to the variation of $\mathrm{G}$ in the period $(t=0.75 \mathrm{sec}$ to $t=1.35 \mathrm{sec})$, while, this output voltage is reduced according to the variation of $\mathrm{T}$ in the period $(\mathrm{t}=1.6 \mathrm{sec}$ to $\mathrm{t}=1.85 \mathrm{sec}$ ) as shown in figure 13.a. Figure 13.b shows the time response of the output current of $\mathrm{PV}\left(\mathrm{I}_{\mathrm{PV}}\right)$ during variation of irradiance $(\mathrm{G})$ and temperature $(\mathrm{T})$. From this figure, the output current is decreased and increased according to the variation of irradiance in linear fashion the period $(\mathrm{t}=0.75$ sec to $\mathrm{t}=1.35 \mathrm{sec})$. On the other hand, this output current is changed slightly due to the temperature variation in the period $(\mathrm{t}=1.6 \mathrm{sec}$ to $t=1.85 \mathrm{sec})$. Also, the time response of output power of $\mathrm{PV}$ array $\left(\mathrm{P}_{\mathrm{PV}}\right)$ is shown in figure 13.c. This figure illustrates that the variation of $\mathrm{P}_{\mathrm{PV}}$ is depended on the variation of $V_{P V}$ and $I_{P V}$. The value of the output power generated from the $\mathrm{PV}$ array is approximately equal to $99.27 \%$ from its maximum value $(99.99 \mathrm{~kW})$. The duty cycle of DC-DC boost converter is adjusted using variable step-size as shown in figure 13.d in order to extract MPP from the PV array and reduce oscillations in the output power. In this method, the output power of PV array is improved with using the modified algorithm and has less oscillation as compared to the conventional one. 


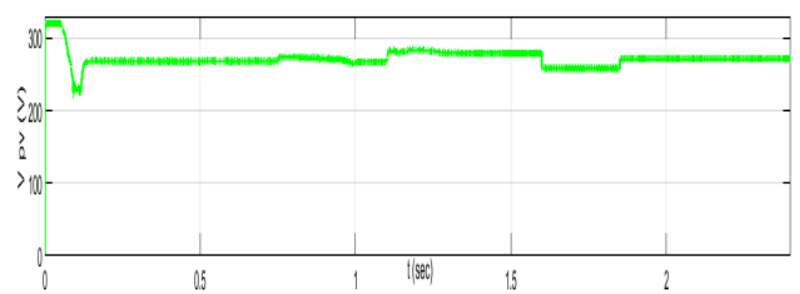

(a): The PV array output voltage $\left(\mathrm{V}_{\mathrm{PV}}\right)$.

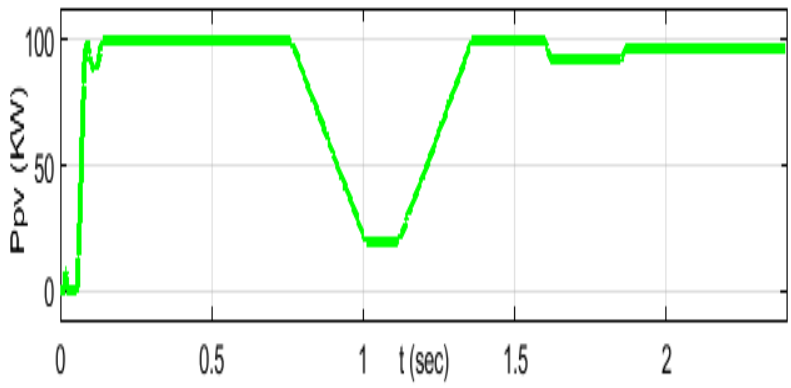

(c): The PV array output power $\left(\mathrm{P}_{\mathrm{PV}}\right)$.

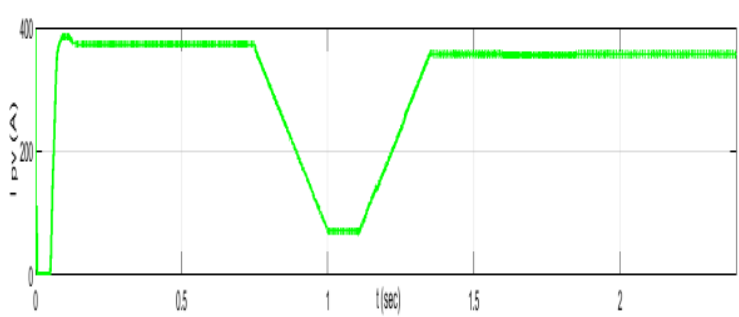

(b):The PV array output current $\left(\mathrm{I}_{\mathrm{PV}}\right)$.

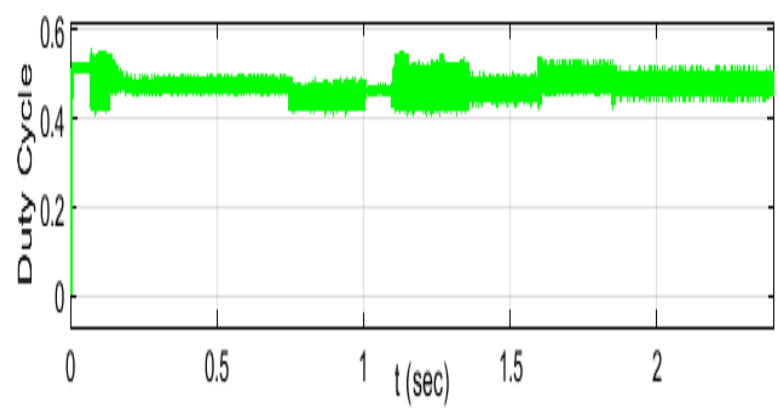

(d): The duty cycle of the converter.

Fig.12: The performance of $P V$ array during variation of irradiance $(G)$ and temperature $(T)$ with the modified $P \& O$ algorithm.

Figure 13 shows the output power of PV array without MPPT, with the conventional $\mathrm{P} \& \mathrm{O}$ and with the proposed $\mathrm{P} \& \mathrm{O}$ algorithm during the variation of irradiance and temperature for comparison purposes. The waveforms of the output power display that the modified $\mathrm{P} \& \mathrm{O}$ technique can achieve MPPT accurately under varying irradiance and temperature levels with less oscillation as compared to the conventional

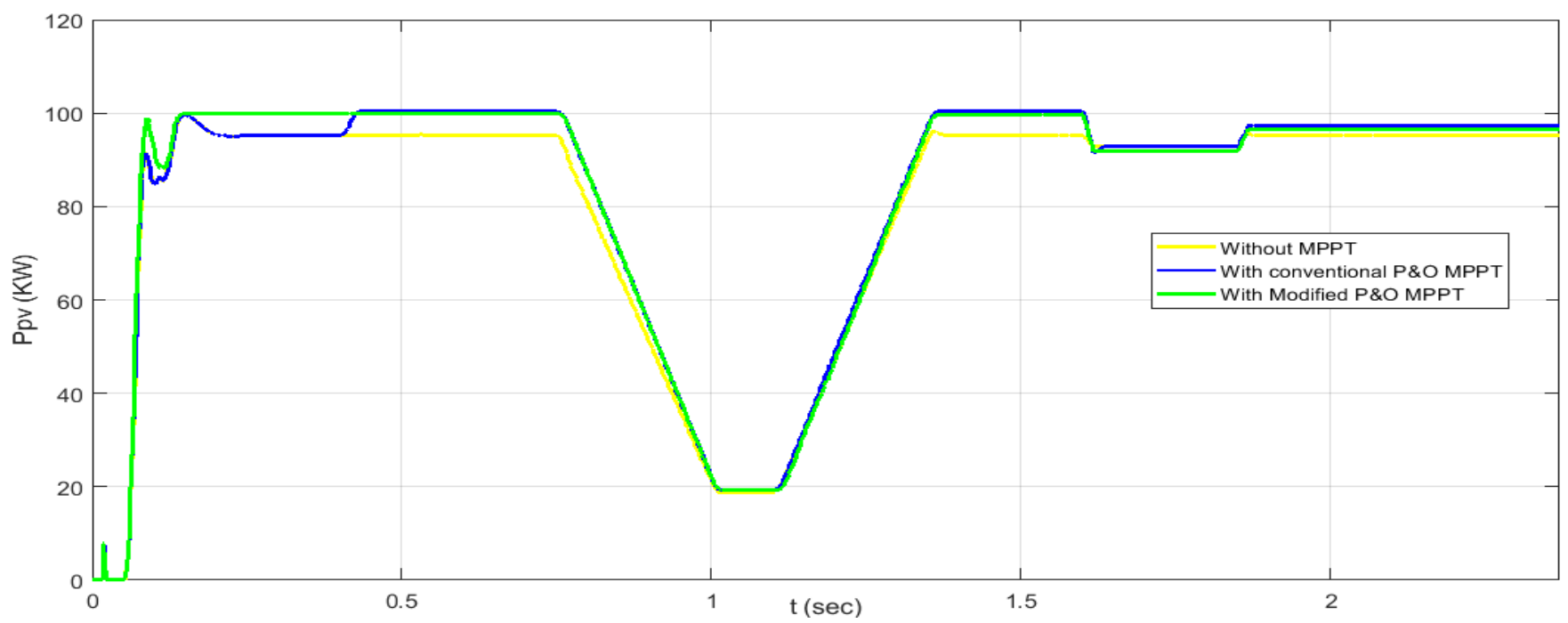

Fig.13: Comparision between the output power of PV array without MPPT, with the conventional $\mathrm{P} \& \mathrm{O}$ and with the modified P\&O algorithm. 


\section{Vol. 40, No. 1. January 2021}

Table 2 demonstrates the output voltage, current and power of PV system obtained from the $\mathrm{I}-\mathrm{V}$ and $\mathrm{P}-\mathrm{V}$ characteristics at different weather conditions. The comparison between the PV array output for the three cases study are presented and tabulated in table 4 .

Table 2: The output of PV array based on I-V and P-V characteristics at different weather conditions.

\begin{tabular}{|c|c|c|c|c|c|}
\hline \multirow{2}{*}{ Case. No } & \multirow{2}{*}{$\mathbf{G}\left(\mathbf{W} / \mathbf{m}^{2}\right)$} & \multirow{2}{*}{$\mathbf{T}\left({ }^{\circ} \mathbf{C}\right)$} & \multicolumn{3}{|c|}{ The output of PV array } \\
\cline { 3 - 6 } & & & $\begin{array}{c}\text { Voltage } \\
(\mathbf{V})\end{array}$ & $\begin{array}{c}\text { Current } \\
(\mathbf{A})\end{array}$ & $\begin{array}{c}\text { Power } \\
\text { (KW) }\end{array}$ \\
\hline 1 & 1000 & 25 & 273.5 & 368.3 & 100.73 \\
\hline 2 & 900 & 25 & 274.6 & 328.7 & 90.26 \\
\hline 3 & 600 & 25 & 271.8 & 220.3 & 59.88 \\
\hline 4 & 500 & 25 & 270.2 & 183.9 & 49.69 \\
\hline 5 & 350 & 25 & 267.9 & 128.7 & 34.48 \\
\hline 6 & 200 & 25 & 263.1 & 73.56 & 19.35 \\
\hline 7 & 1000 & 50 & 250.2 & 371.4 & 92.92 \\
\hline 8 & 1000 & 35 & 264.4 & 368.5 & 97.43 \\
\hline
\end{tabular}

Table 3: Comparison between PV system without and with MPPT at different weather conditions.

\begin{tabular}{|c|c|c|c|c|c|c|c|c|c|}
\hline \multirow{3}{*}{ Case. No } & \multirow{2}{*}{\multicolumn{3}{|c|}{$\begin{array}{c}\text { PV array output without using } \\
\text { MPPT }\end{array}$}} & \multicolumn{6}{|c|}{ PV array output with MPPT } \\
\hline & & & & \multicolumn{3}{|c|}{ Conventional P\&O } & \multicolumn{3}{|c|}{ Modified P\&O } \\
\hline & $\begin{array}{l}\text { Voltage } \\
\text { (V) }\end{array}$ & $\begin{array}{l}\text { Current } \\
\text { (A) }\end{array}$ & $\begin{array}{l}\text { Power } \\
(\mathbf{k W})\end{array}$ & $\begin{array}{l}\text { Voltage } \\
\text { (V) }\end{array}$ & $\begin{array}{l}\text { Current } \\
\text { (A) }\end{array}$ & $\begin{array}{c}\text { Power } \\
(\mathbf{k W})\end{array}$ & $\begin{array}{l}\text { Voltage } \\
\text { (V) }\end{array}$ & $\begin{array}{l}\text { Current } \\
\text { (A) }\end{array}$ & $\begin{array}{c}\text { Power } \\
(\mathbf{k W})\end{array}$ \\
\hline 1 & 249.6 & 381.77 & 95.37 & 285.32 & 341.5 & 98.25 & 268.33 & 372.76 & 99.99 \\
\hline 2 & 242.33 & 346.35 & 86.51 & 285.4 & 307.68 & 90.41 & 274.45 & 330.41 & 93.42 \\
\hline 3 & 241.58 & 229.95 & 58.4 & 238.9 & 230.17 & 60.51 & 273.22 & 219.05 & 62.94 \\
\hline 4 & 241.39 & 191.92 & 48.86 & 289.44 & 154.56 & 50.11 & 269.59 & 134.67 & 52.52 \\
\hline 5 & 241.24 & 135.44 & 35.18 & 231.65 & 234.6 & 35 & 271.95 & 127.77 & 37.56 \\
\hline 6 & 248.06 & 76 & 18.83 & 235.9 & 76.68 & 18.99 & 264.95 & 73.01 & 22.05 \\
\hline 7 & 249.63 & 372.2 & 92.89 & 261.7 & 345.85 & 91.53 & 258.73 & 354.44 & 91.8 \\
\hline 8 & 249.62 & 381.13 & 95.14 & 275.79 & 343.55 & 95.44 & 271.35 & 355.74 & 96.65 \\
\hline
\end{tabular}

\section{CONCLUSION}

Simulation results of PV system connected to the grid with the modified perturb and observe technique are carried out for achieving MPPT using Matlab/Simulink software package. The modified perturb and observe technique based on variable step-size is proposed in this paper to achieve MPPT and improve the system performance. The performance of PV array connected to grid is obtained at different weather conditions. Also the performance of PV system is obtained using conventional 


\section{Vol. 40, No. 1. January 2021}

and modified perturb and observe methods at different weather conditions to achieve MPPT for comprising purposes.

From the present analysis, One can draw the following conclusion:-

1- The response of the generated output voltage of PV array is greatly reduced due to the variation of

temperature and slightly changed with irradiance variation.

2- The response of the generated output current of PV array is linearly decreased and increased due to the variation of irradiance and slightly changed with temperature variation.

3- The response of the generated output power of PV array is changed depending on the variation of the PV output voltage and current.

4- The value of the generated output power from PV system using MPPT algorithms is a good tracking with its maximum value of $\mathrm{PV}$ system and its time response is improved using the proposed algorithm as compared to the conventional one.

5- Better performance of PV system have been achieved with minimum oscillation with using the modified perturb and observe algorithm as compared to the conventional one.

\section{REFERENCES}

[1] Jitendra, K. Vinod, K. Dr.R, R. J. and Jai, K. M., Design of grid connected photovoltaic system employing incremental conductance MPPT algorithm, Journal of Electrical Engineering, 12, 172-177, 2012.

[2] Ratna, I. P. Sapto, W. and Muhamad, R. i., Maximum power point tracking for photovoltaic using incremental conductance method, Energy Procedia, 68, 22-30, 2015.

[3] Kaustubh, S. B. Aniket, G. Chetan, A. and R, S., Modeling \& Simulation of Proposed 25 KW Solar PV Power Plant for SSGMCE, Shegaon,
International Journal for Scientific Research \& Development-IJSRD 7,431-434, 2019.

[4] Omar, M. B. Samir, H. and Sid, A. Zidi., Modeling and simulation of grid connected PV generation system using Matlab/Simulink, International journal of power electronics and drive systems, 8 (1), 392, 2017.

[5] Hifsa, S. Muhammad, K. Zeeshan, M. Muhammad, Y. S. Muhammad, M. and Karrar, H., Implementation of the novel temperature controller and incremental conductance MPPT algorithm for indoor photovoltaic system, Solar Energy, 163, 235-242, 2018.

[6] Arjav, H. Abhishek, B. and Mrutyunjaya, S., Study of maximum power point tracking (MPPT) techniques in a solar photovoltaic array, 2011.

[7] J, S. K. Dr.Ch, S, B. and A, K. B., Design and analysis of $\mathrm{P} \& \mathrm{O}$ and IP\&O MPPT techniques for photovoltaic system, International Journal of Modern Engineering Research, 2 (4), 2174-2180, 2012.

[8] Bhatnagar, P. and Nema, R. K., Maximum power point tracking control techniques: State-ofthe-art in photovoltaic applications, ELSEVIER Renewable and Sustainable Energy Reviews, 23, 224-241, 2013.

[9] Montaser, A., Study, Design and Performance Analysis of Grid-Connected Photovoltaic Power Systems, PHD Thesis, Minia University, 2015.

[10] Henrik, Z. Nóra, H. B. Szilvia, C. András, V. and Gábor, P., Economic Analysis of GridConnected PV System Regulations: A Hungarian Case Study, Electronics, 8 (2), 149, 2019.

[11] Rophika, S. P., Comparative study of P\&O and Incremental Conductance MPPT algorithms for

Photovoltaic System, International Journal of Innovations in Engineering and Technology, 5, 200-206, 2016.

[12] Almas, H. M. Prof.G. K. P. and Prof.P. K. S., Three Phase Grid Connected Photovoltaic System with Maximum Power Point Tracking, International Journal of Advanced Research in Electrical,Electronics and Instrumentation Engineering, 4 (5), 4637-4647, 2015.

[13] Vladimir, L. Zahari, Z. Ludmil, S. Hristiyan, $\mathrm{K}$. and Bruno, F., GRID-CONNECTED PV SYSTEM WITH MPPT CONTROL, 63, 357366, 2013.

[14] Ali, A. G. Seyed, M. S. and Asma, S., A high performance maximum power point tracker for PV systems, International Journal of Electrical Power \& Energy Systems, 53, 237243, 2013. 
[15] Kandemir, E. Borekci, S. and Cetin, N. S., Conventional and Soft-Computing Based MPPT Methods Comparisons in Direct and Indirect Modes for Single Stage PV Systems, Elektronika ir Elektrotechnika, 24 (4), 45-52, 2018.

[16] A, D. hemici, b. and Adil, Y., Modified perturb and observe MPPT control for avoid deviation in photovoltaic systems, Journal of Electrical Engineering, 17, 28-37, 01/01 2017.

[17] Azadeh, S. and Saad, M., Simulation and Hardware Implementation of Incremental Conductance MPPT With Direct Control Method Using Cuk Converter, IEEE TRANSACTIONS ON INDUSTRIAL ELECTRONICS, 58, 11541161, 2011.

[18] Muralidhar, K. and Susovon, S., Modified perturb and observe MPPT algorithm for drift avoidance in photovoltaic systems, IEEE transactions on Industrial Electronics, 62 (9), 5549-5559, 2015.

[19] Ashish, P. Nivedita, D. and Ashok, K., Mukerjee., High-performance algorithms for drift avoidance and fast tracking in solar MPPT system, IEEE Transactions on Energy Conversion, 23 (2), 681-689, 2008.

[20] Fangrui, L. Shanxu, D. Fei, L., Bangyin, L. and Yong, K., A variable step size INC MPPT method for PV systems, IEEE Transactions on industrial electronics, 55 (7), 2622-2628, 2008.

\section{List of Symbols}

\begin{tabular}{|c|c|}
\hline I & Cell current (A); \\
\hline $\mathrm{I}_{\mathrm{ph}}$ & $\begin{array}{l}\text { Light generated } \\
\text { current(Photo-current) (A); }\end{array}$ \\
\hline $\mathrm{I}_{\mathrm{S}}$ & Diode saturation current (A); \\
\hline $\mathrm{q}$ & Charge of electron $=1.6 \times 10^{-19}(\mathrm{C})$; \\
\hline K & Boltzmann constant $(\mathrm{J} / \mathrm{K})$; \\
\hline V & Cell output voltage $(\mathrm{V})$ \\
\hline $\mathrm{Rs}, \mathrm{Rp}$ & Cell series and shunt resistance $(\Omega)$ \\
\hline G & Cell surface irradiance $\left(\mathrm{W} / \mathrm{m}^{2}\right)$; \\
\hline $\mathrm{G}_{\mathrm{STC}}$ & $\begin{array}{l}\text { Solar irradiance at standard test } \\
\text { conditions (STC); }\end{array}$ \\
\hline $\mathrm{T}$ & Cell working temperature $\left({ }^{\circ} \mathrm{C}\right)$; \\
\hline $\mathrm{T}_{\mathrm{STC}}$ & PV cell temperature at $\mathrm{STC}\left({ }^{\circ} \mathrm{C}\right)$; \\
\hline $\mathrm{I}_{\mathrm{ph}}$ at STC & Photo-current at STC; \\
\hline $\mathrm{K}_{\mathrm{i}}$ & Short circuit current coefficient; \\
\hline
\end{tabular}

$\begin{array}{cl}\mathrm{V}_{\text {in }} & \text { Input voltage }(\mathrm{V}) ; \\ \mathrm{V}_{\text {out }} & \text { Output voltage }(\mathrm{V}) ; \\ \mathrm{I}_{\mathrm{L}} & \text { Input current }(\mathrm{A}) ; \\ \mathrm{I}_{\mathrm{inv}} & \text { Inverter input DC current }(\mathrm{A}) ; \\ \mathrm{L} & \text { Boost inductance }(\mathrm{mH}) ; \\ \mathrm{C} & \text { DC-link capacitor }(\mu \mathrm{F}) ; \\ \mathrm{T}_{\text {on }} & \text { On time period of semiconductor } \\ & \text { switch (Sec); } \\ \mathrm{T}_{\mathrm{Off}} & \text { Off time period of semiconductor } \\ & \text { switch (Sec); } \\ \mathrm{D} & \text { Duty cycle; } \\ \mathrm{d} & \text { The switch state; } \\ \mathrm{VSS} & \text { Variable step-size; } \\ \varepsilon & \text { Power permissible error; } \\ \mathrm{D}(\mathrm{k}) & \text { Duty cycle of DC-DC converter at } \\ & \text { instant k; } \\ \mathrm{D}(\mathrm{k}-1) & \text { Previous value of duty cycle of DC- } \\ & \text { DC converter at instant k-1; } \\ \mathrm{SF} & \text { Scaling factor. }\end{array}$




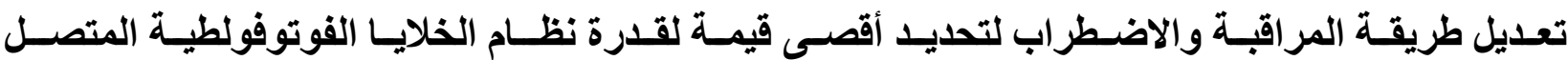

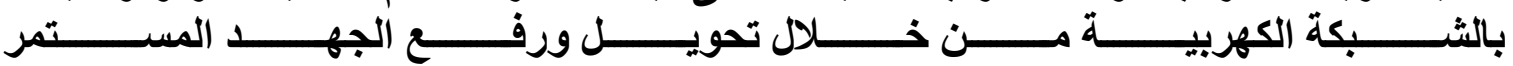

\author{
ابرام يحى فوزى '، يحى سيد محمَ" ، عماد جميل شحاتة" ، منتصر عبد الستار”

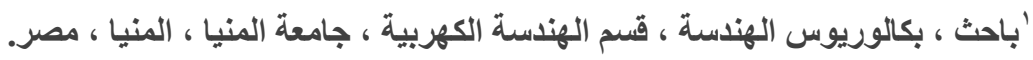 \\ ץ أستاذ ورئيس قسم الهندسة الكهربية ، كلية الهندسة ، جامعة المنيا ، المنيا ، مصر.

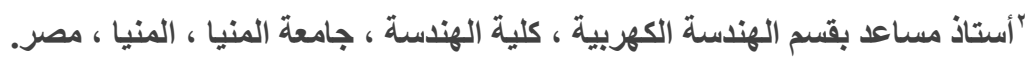 \\ "مدرس بقسم الهندسة الكهربية والحاسبات ، المعهد العالى للهندسة والتكنولوجيا ، المنيا ، مصر.

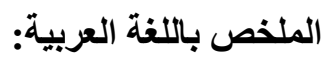

يتناول البحث تصميم نظام خلايا شمسية (منظومة فوتوفولتية) متصل بالثبكة الكهربية من خلال عاكس ثلاثى الأوجه و التحكم فى هذا النظام بالاعنماد على تقنيات تتبع أقصى قيمة قدرة لنظام الخلايا الفوتوفولطية فى ظل ظروف مختلفة من الاشعاع الثمسى ودرجة الحر ارة. قد تم اقتر اح تعديل لطريقة المر اقبة والاضطر اب فى هذا البحث لتتبع أقصى قيمة قدرة لنظام الخلايا الفوتوفولطية من خلال تحويل ورفع الجهد المستمر حيث تستخدم هذه الطريقة للحصول على قدرات أفضل وتذبذبات أقل عند الحالة المستقرة وقد تم محاكاة النظام باستخدام برنامج المحاكاة (Matlab/Simulink) لتوضيح الفرق بين أداء النظام مع وبدون استخدام تقنيات تتبع أقصى قدرة للخلايا الثمسية فى ظل مستويات مختلفة من الاشعاع الثمسى ودرجة الحرارة. وقد اثبتت نتائج المحاكاة أن النظام الئـعدل يستطيع تتبع أقصى قيمة قدرة للخلايا الثمسية بدقة بالإضافة إلى إمكانية الحصول على ملى قدرات أفضل أثناء تغير الظروف الجوية بالمقارنة مع النظام التقليدى لطريقة المر اقبة والاضطر ابلاب. 